Volume 4 • Nomor 2 • Februari 2021

Pege (Hal.) : 197 - 211

(C) Universitas Pamulang

JL.Surya Kencana No.1 Pamulang, Tangerang Selatan - Banten

Telp. (021) 7412566, Fax (021) 7412491

website. :

Email : jurnalmarketing.unpam@gmail.com

\title{
Model Platform E-Commerce Dalam Mendukung Kesuksesan Bisnis Usaha Mikro Kecil \& Menengah(UMKM)
}

\author{
Tedy Ardiansyah \\ Universitas Indraprasta PGRI Jakarta email ; tedyardiansy4h@gmail.com
}

\begin{abstract}
Abstrak. Model Platform E-Commerce Dalam Mendukung Kesuksesan usaha bisnis Mikro, Kecil dan Menengah(UMKM) di Indonesia. Riset tentang keberhasilan Usaha Mikro, Kecil dan Menengah (UMKM) di nusantara bisa dihitung dengan jari, tentunya mengenai e-commerce terutama pada platform atau aplikasi tidak hanya itu saja, namun support dan model bisnis dari UMKM menjadi bagian kunci dari kesuksesan UMKM. Penelitian ini bertujuan untuk membentuk model keberhasilan usaha mikro melalui platform e-commerce. Metode Penelitian: Pendekatan ini dilakukan dengan menggunakan penelitian kualitatif menggunakan metodologi baru yang diusulkan yang menggabungkan pendekatan tinjauan literatur sistematis untuk mengidentifikasi artikel yang paling relevan untuk dimasukkan dalam penelitian dengan analisis jaringan kutipan untuk mengungkap dinamika bidang yang diteliti. Metodologi baru ini penulis definisikan sebagai analisis jaringan literatur yang sistematis, Hasil: Pemodelan platform E-commerce(perdagangan elektronik) bagi para pelaku bisnis digital untuk mendukung keberhasilan UMKM di Indonesia. Kesimpulan dari penelitian ini menunjukkan bahwa bentuk model yang tepat untuk kesuksesan UMKM di Indonesia melalui platform e-commerce dari berbagai pelaku bisnis digital.
\end{abstract}

Kata Kunci: Platform; e-commerce; Usaha Mikro Kecil Menegah; sukses

Abstract. E-Commerce Platform Model In Supporting Independent Micro Business Success. Research on the success of Mandiri Micro Enterprises (MSMEs) in the archipelago can be counted on the fingers, of course regarding e-commerce, especially on platforms or applications, not only that, but support and business models from MSMEs are a key part of the success of SMEs. This study aims to form a model for the success of micro-businesses through e-commerce platforms. Research Method: This approach is carried out using qualitative research using a proposed new methodology that combines a systematic literature review approach to identify the most relevant articles for inclusion in the research with citation network analysis to uncover the dynamics of the field under study. The author defines this new methodology as a systematic literature network analysis, Result: Modeling an electronic commerce platform (e-commerce) for digital business players to support the success of SMEs in Indonesia. Conclusion: e. The conclusion from this research shows that the form of the right model for the success of SMEs in Indonesia through ecommerce platforms from various digital business players.

Keyword: Platform; e-commerce; SMEs; success 


\section{A. PENDAHULUAN}

Teknologi Data dan Komunikasi (TIK) secara mendasar mengubah intensitas asosiasi, misalnya, Internet telah mereformasi cara bisnis dijalankan karena peningkatan serius dalam inovasi di bidang TIK. Pemanfaatan Internet dalam hubungannya dengan bidang TIK lainnya. Segmen mengubah cara bisnis dilakukan secara lokal dan di seluruh dunia (Payne, 2001). Web, yang terhubung ke organisasi komputer, adalah alat bisnis yang penting, kuat, dan berkembang pesat karena mudah beradaptasi, bijaksana, dan mudah digunakan. Kebangkitan dan prevalensi perusahaan bisnis yang mendukung web untuk mendapatkan lebih banyak klien dan meningkatkan perhatian publik pada organisasi, administrasi, dan item mereka. Pemanfaatan TIK yang berkisar dari komputer terpusat hingga individu yang menggunakan internet, dari penanganan kata hingga aplikasi dan kerangka kerja yang ditingkatkan telah membuat kemajuan luas menjadi asosiasi yang sangat besar, menengah, dan bahkan kecil(Doukidis et al., 1996).

Usaha Mikro, Kecil dan Menengah (UMKM) telah mengisi peran penting dalam ekonomi dunia selama beberapa tahun terakhir. Bahkan ada sejumlah contoh pemanfaatan TIK untuk bisnis online dalam penciptaan bangsa. UMKM adalah basis perekonomian, semua hal dipertimbangkan, termasuk perbaikan (Amoako et. al, 2020, Hatammimi et al., 2014, Yunis et al., 2017, Her, 2020). Mereka tidak dapat ditinggalkan dan sekarang banyak yang menunjukkan kualitas giat mereka dengan memahami keadaan yang ditawarkan oleh bisnis berbasis web (Payne, 2001). Di sebagian besar negara maju, UKM terdiri dari area pergerakan keuangan yang sangat unik dan penting yang, oleh dan oleh, perlu mengelola bobot tinggi yang serius dan kekurangan aset. ICT menawarkan UMKM peluang besar untuk berkembang dan bersaing dalam iklim bisnis saat ini (Payne, 2001). Di Indonesia, UMKM telah terbukti menjadi bagian utama dalam membangun keuangan daerah, terutama sebagai perusahaan besar sebagai pemasok utama lapangan kerja, dan kemudian menjadi penghasil jenis pendapatan penting atau tambahan untuk beberapa unit keluarga (Tambunan, 2006). Hal tersebut juga sangat berpengaruh atau berkorelasi dengan pasar layanan digital, yang tentunya terkait dengan penyediaan platform elektronik dalam mendukung kemajuan kegiatan UMKM di seluruh nusantara.

Para juara bisnis digital di Indonesia telah berhasil membangun platform bisnis yang menciptakan saling ketergantungan dan simbiosis mutualisme antar perusahaan UMKM. Namun, apakah platform ini akan menjadi sarana yang ampuh bagi jutaan UMKM untuk memperbanyak bisnis dan platform mana yang dapat membangun ekosistem yang merangkul dan memberdayakan UMKM. Beranjak dari latar belakang tersebut, maka peneliti akan menyajikan tinjauan pustaka mengenai model platform e-commerce bagi para pelaku bisnis digital dalam mendukung keberhasilan UMKM di Indonesia.

\section{B. KAJIAN LITERATUR}

Usaha Mikro, Kecil, dan Menengah (UMKM), dipengaruhi oleh 7 faktor dalam skala makro dalam mempengaruhi kegiataan usaha antara lain (Niode, 2009):

1. Kesulitan pemasaran.

Seringkali UMKM mengalami kendala dalam melakukan pemasaran, apalagi saat ini segala sesuatu harus lebih cepat dan tanggap atas permintaan dari konsumen. Secara umum pelaku UMKM tidak memahami hal demikian dan tentunya yang menyangkut dengan teknologi. Padahal untuk mengatasi kesulitan dalam memasarkan produk atau jasa UMKM, harus melakukan digitalisasi, apalagi saat ini masa pandemi, penetrasi pasar di masa pandemi ini, tentu membutuhkan digitalisasi yang mana juga mendukung penterasi pasar yang bersifat luring atau offline.

2. Keterbatasan sumber daya manusia. 
Sebagian Sumber Daya Manusia di sektor UMKM ini masih rendah, rata-rata hanya sekolah dasar, di Indonesia 51\% tenaga kerja pendidikannya sekolah dasar, sehingga amat sulit untuk menerapkan keunggulan daya, tentunya saat ini berhubungan dengan teknologi. Kunci utama untuk meningkatkan kualitas UMKM harus dimulai dari sisi SDM yang terus ditingkatkan kualitas baik melalui pelatihan-pelatihan atau perekrutan pekerja yang selektif. Selain itu menjadi Pekerjaan Rumah Pemerintah dalam meningkatkan daya saing UMKM yaitu mengubah pola UMKM yang mayoritas UMKM konsumen menjadi UMKM produsen. Hal yang paling mempengaruhi adalah bahan baku produk UMKM yang masih banyak di impor. Pemerintah diminta untuk melakukan koreksi untuk menyongsong bonus demografi Indonesia. Banyaknya penduduk harus dimanfaatkan untuk menjadikan Indonesia Negara produsen bukan konsumen.

3. Teknologi terbatas.

Pada masa pandemic covid-19 ikut menyerang sektor UMKM, padahal sektor ini biasanya menjadi penolong perekonomian dalam fase krisis. Digitalisasi pun dipandang dapat menjadi solusi bagi para UMKM untuk bertahan pada masa pandemi. Namun UMKM yang telah masuk kedalam ekosistem digital masih sangat minim. Berdasarkan data kementrian Koperasi dan UKM dari total 64,19 juta pelaku UMKM ditanah air, baru 13 persen yang terhubung dengan pasar daring atau marketplace. Pemahaman teknologi pada pelaku UMKM masih rendah, kendala lainnya adalah akses internet yang terbatas, padahal akses internet jadi syarat kunci UMKM bisa go digital, namun kenyataannya sebagian pelaku usaha UMKM tersebar didaerah masih terbatas jaringan internetnya. Keterbatasan modal dan infrastruktur teknologi yang memadai, UMKM butuh perangkat ponsel pintar maupun gawai lain yang mendukung pemasaran produk secara daring.

4. Keterampilan manajerial.

Ketrampilan yang lebih difokuskan dalam mengatur sumber daya manusia dengan baik sehingga pencapain tujuan dapat digapai dengan masimal, ada hal yang paling penting dari pengelolaan manajerial yaitu berkaitan dengan ketrampilan menyangkut dengan penaataan atau manajemen kuangan, hal ini sangat mempunyai pengaruh yang signifikan dalam keterampilan menyangkut manajerial.

5. Kemitraan.

Kemitraan adalah hal yang paling penting dalam melakukan kegiatan penetrasi usaha kewirausahaan, dengan adanya kemitraan membentuk suatu jaringan yang kuat sehingga pencapaian hasil dapat dilakukan maksimal atau setidak meminimkan risiko kerugian yang terjadi dimasa yang akan datang.

Bisnis online dapat dicirikan sebagai tindakan moneter atau bisnis melalui jalur ritel Web untuk memberdayakan pembelian dan penjualan barang dan administrasi dan untuk mendorong pertukaran dan latihan bisnis antara dan di antara orang-orang dan asosiasi (Schneider, 2002).

Secara garis besar e-commerce dimaksudkan kegiatan online dalam melakuakn jual beli, dimana hal ini bisa di suatu tempat secara bersama-sama atau secara individu. Proses jual beli yang menyangkut keuntungan pastinya berhubungan dengan nilai mata uang melewati garis-gari dari suatu kelompok besar maupun secara retail dengan Transaksi berupan produk baik barang maupun jasa (Keneth, 2007)..

Berdasarkan kajian di atas maka penelitian akan mengidentifikasi berbagai permasalahan atau kendala yang menghubungkan platform atau aplikasi e-commerce dengan kegiatan usaha mikro atau usaha kecil dan menengah di Indonesia; Hal ini akan membantu dalam membentuk model kegiatan usaha mikro atau usaha kecil menengah di Indonesia. 


\section{METODOLOGI PENELITIAN}

Penelitian kualitatif dilakukan dengan pendekatan tinjauan pustaka sistematis, hal ini untuk mendapatkan hasil yang diinginkan secara jelas dan terperinci sehingga kedapan akan membantu menjawab terutama dalam hal project map atau model dalam permasalahan yang dihadapi dan tentu membantu menjawab permasalahan dengan rinci dan tepat.

Objek penelitian yang dilakukan adalah leader dari 5 platform atau aplikasi $e$ commerce di Indonesia, antara lain Bukalapak, Tokopedia, Kudo, Grab, dan Gojek. Data diambil dari data sekunder yang sudah ada dari hasil wawancara tempat penyusunan wawancara.

Tinjauan pustaka sistematis atau Systematic Literatur adalah proses linier yang logis, di mana setiap bagian berada diinformasikan oleh sebelumnya itu. Beberapa jenis pertanyaan tinjauan mungkin ditanyakan; yang umum adalah intervensi yang membandingkan, tes diagnostik, faktor prognostik, atau pertanyaan kualitatif. Pendekatan untuk masing-masing sedikit berbeda, tetapi prinsip umumnya tetap ada sama. Ada sejumlah standar yang harus diikuti, serta alat yang bisa digunakan. Kriteria kelayakan logis itu penting seolah-olah ini tidak benar, semuanya berikut ini juga akan salah. Ini serupa dengan menetapkan kriteria untuk memasukkan peserta ke studi(Purssell \& McCrae, 2020). Sebagai tugas akademis, tinjauan pustaka adalah tempat Anda menunjukkan bahwa Anda berdua menyadari dan bisa mengartikan apa yang sudah diketahui dan dimana akhirnya anda akan mampu menunjukkan kontradiksi dan kesenjangan dalam pengetahuan yang ada. Sebagai dengan penelitian apa pun, Anda harus menjelaskan mengapa ulasan Anda penting, mengapa berbeda dan apa yang menambah pengetahuan. Dalam penelitian, kami mencari menjadi orisinal dan memberikan kontribusi orisinal untuk pengetahuan. Dalam konteks tinjauan pustaka, itu berarti menciptakan dimensi baru atau perspektif baru yang memberikan kontribusi berbeda. Ada banyak alasan untuk dibawa ulasan literatur, sehingga siswa harus memastikan bahwa mereka mengetahui apa mereka diminta untuk melakukan dan memastikan bahwa tinjauan mereka melakukan apa yang diminta. Diambil sebagai bentuk tradisionalnya yang paling sederhana dari tinjauan pustaka adalah 'tinjauan' dari literatur. Setiap siswa di beberapa titik dalam karir akademis mereka diminta untuk melakukan tinjauan pustaka, biasanya sebagai bagian dari menyelesaikan proyek Penelitian. Terkadang tugasnya hanya untuk melakukan tinjauan pustaka sebagai disertasi dalam dirinya sendiri. Jadi mari kita mulai dengan definisi(Jesson, Matheson, \& Lacey, 2011).

Dalam pendekatan penelitian kualitatif dengan studi literatur ini, peneliti menggunakan alat NVivo 10, yaitu alat yang diakui secara internasional untuk melakukan penelitian kualitatif (Jackson et al., 2013,Woolf et al., 2018) Analisis yang dilakukan adalah bagian dari alat yang disediakan oleh aplikasi NVivo 12. Analisis yang digunakan adalah Analisis Word Frequencies Queries, Cluster Analysis, dan Project Map Analysis.

\section{HASIL DAN PEMBAHASAN}

\section{Hasil}

Platform e-commerce bagi para pelaku bisnis digital dalam mendukung kesuksesan UKM di Indonesia sangat penting dalam menunjang kegiatan usahanya (Rusgowanto, 2020,Qosasi et al., 2019,Siahaan et al., 2020). Hasil penelitian dalam penelitian ini disajikan secara lengkap dalam matriks wawancara masing-masing pimpinan, terlampir di bawah ini yang menjelaskan tentang dukungan bagi UKM atau UMKM dan model bisnis 
platform e-commerce bagi para pelaku bisnis digital sebagai berikut (Elsi anismar et. al, 2019).

Dari tabel di bawah ini, 5 pelaku bisnis digital yaitu Bukalapak, Tokopedia, Kudo, Grab dan Gojek terbagi menjadi dua bagian yaitu Pendukung UKM dan Model Bisnis untuk memudahkan mencari program atau kegiatan yang mendukung kemajuan mikro atau kecil dan menengah. perusahaan dalam menggunakan e-commerce untuk kebutuhan bisnis:

Table 1. Pemain Digital Bisnis

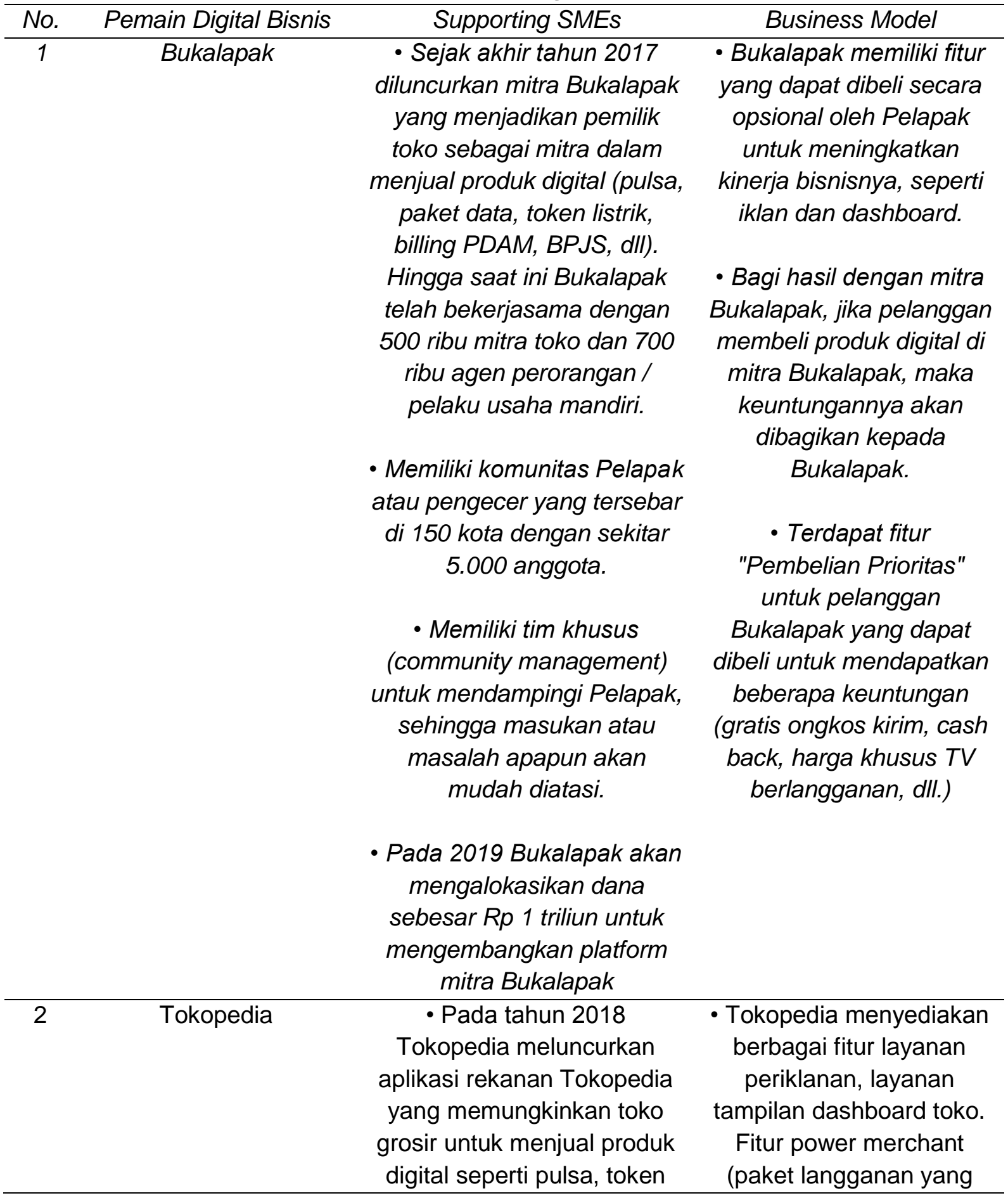




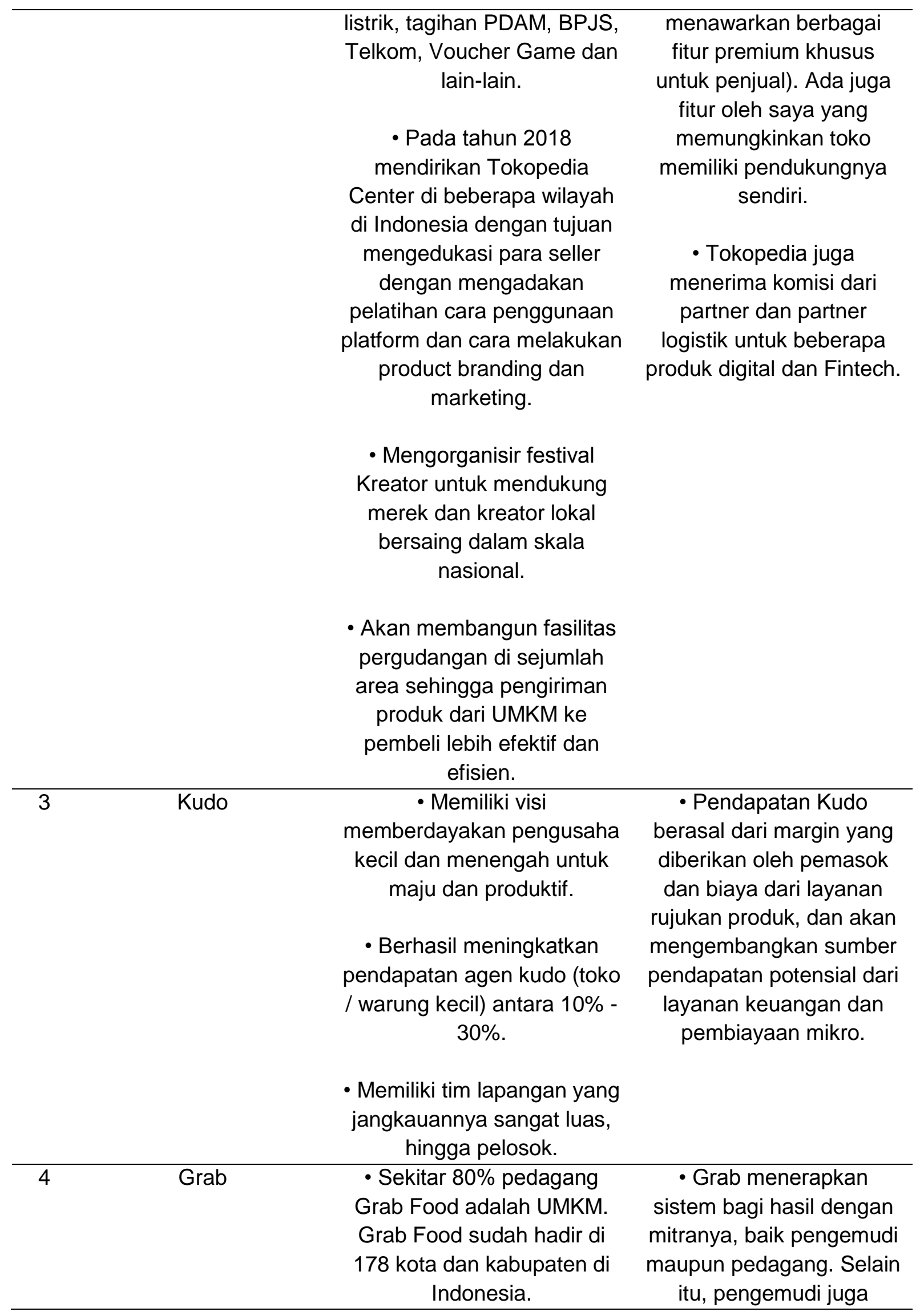




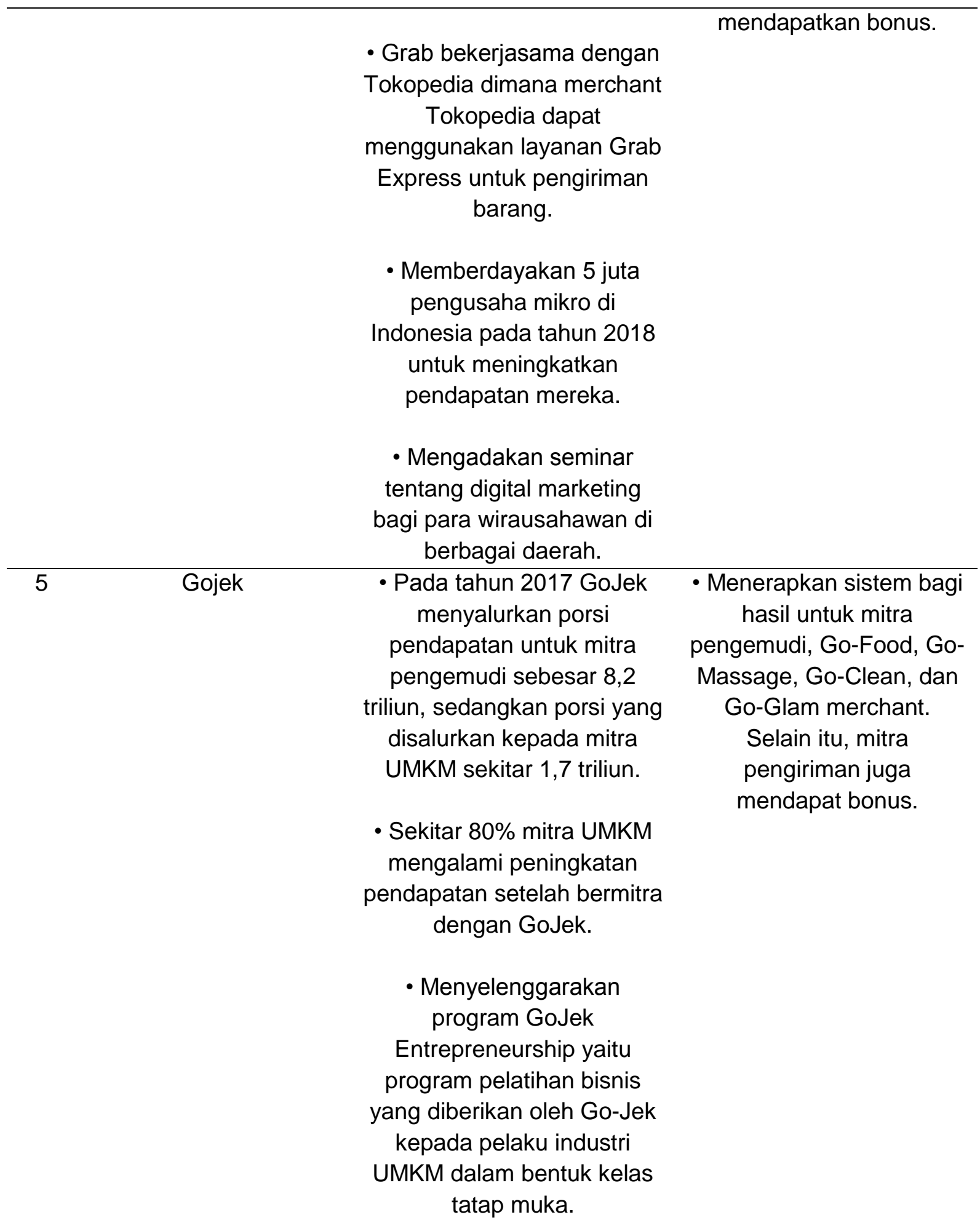




\section{Pembahasan}

\section{Word Frequency Queries}

Yakni mengeksplorasi kata-kata yang paling sering muncul dalam data penelitian. Dengan alat analisis ini, kata-kata yang memiliki arti yang sama dapat dikategorikan ke dalam kelompok yang sama

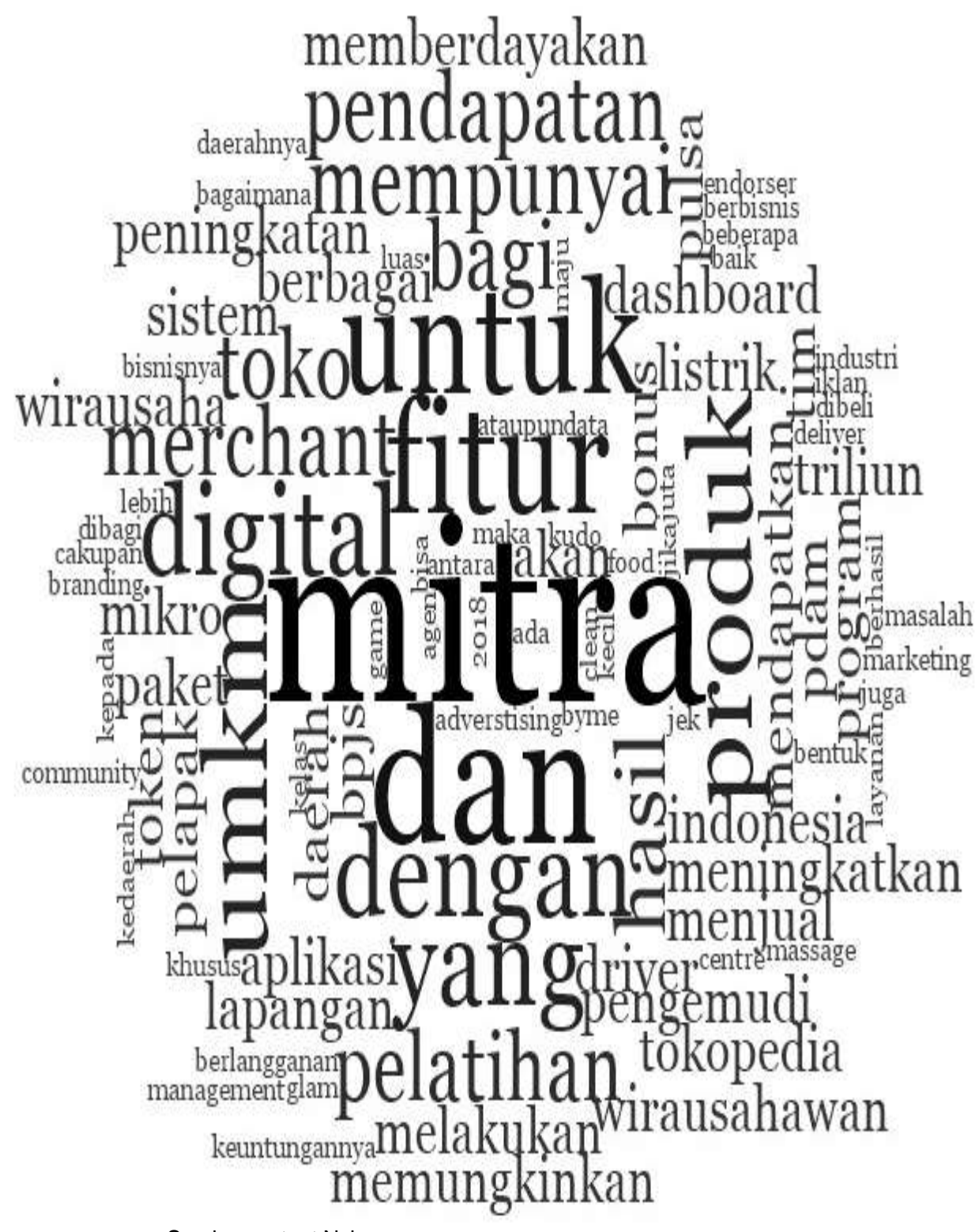

Sumber: output Nvivo

\section{Gambar 1. Word Frequency Queries}

Dari analisis diatas maka kata yang paling dominan adalah Mitra, Fitur, Produk, UKM, Digital, merchant dan toko, dapat diartikan bahwa semua pelaku bisnis digital fokus pada platform e-commerce terutama yang dicetak tebal. Nantinya dalam coding, Mitra digunakan sebagai komunitas(Community), untuk Fitur sebagai Fitur Aplikasi(Feature Application), kemudian produk digital(Selling Digital Products), merchant, dan toko digunakan sebagai tempat menjual produk digital. 


\section{Cluster Analysis}

Analisis cluster adalah metodologi eksplorasi yang digunakan untuk memvisualisasikan desain proyek dengan mengelompokkan sumber atau node dengan istilah serupa, nilai atribut serupa, atau serupa dengan node. Diagram cluster analisis menawarkan sumber grafis atau representasi node untuk menampilkan kemiripan dan perbedaan. Untuk kenyamanan, sumber atau node dalam diagram analisis cluster serupa dan tidak berbeda. Beberapa jenis analisis cluster antara lain peta cluster 2D, peta cluster 3D, dendrogram horizontal, dendrogram vertikal, dan grafik lingkaran. Saat ini peneliti menggunakan analisis grafik lingkaran cluster. Pada grafik lingkaran, persamaan ditunjukkan dengan garis biru; garis yang lebih tebal menandakan kesamaan lebih kuat. Ketimpangan ditampilkan sebagai garis merah atau tidak memiliki garis.

Bandingkan kata-kata yang terdapat pada sumber data atau ingin membandingkan kesamaan kata dalam hasil pengkodean yang disimpan di node. Dalam Analisis Cluster ini dapat diukur tentang korelasi (Koefisien Pearson).

Tabel 2. Cluster Analysis

\begin{tabular}{|c|c|c|}
\hline File A & File B & $\begin{array}{c}\text { Pearson correlation } \\
\text { coefficient }\end{array}$ \\
\hline Files|lwawancarallTokopedia & Files|lwawancaral|Kudo & 0.218477 \\
\hline Files|lwawancarallTokopedia & Files\lwawancaral|Bukalapak & 0.208126 \\
\hline Files|lwawancarallTokopedia & Files\|lwawancarallGrab & 0.191528 \\
\hline Files\lwawancaral|Gojek & Files|lwawancaral|Bukalapak & 0.131561 \\
\hline Files|lwawancarallGrab & Files|lwawancaral|Gojek & 0.11183 \\
\hline Files|lwawancaral|Kudo & Files|lwawancaral|Gojek & 0.101078 \\
\hline Files|lwawancarallTokopedia & Files|lwawancaral|Gojek & 0.050342 \\
\hline Files|lwawancaral|Kudo & Files॥wawancarallGrab & 0.033319 \\
\hline Files|lwawancarallKudo & Files|lwawancaral|Bukalapak & 0.011473 \\
\hline Files\lwawancarallGrab & Files\lwawancaral\Bukalapak & -0.035662 \\
\hline
\end{tabular}

Sumber: output Nvivo

Jika dilihat dari korelasi antara Pearson Correlation Coefficient semuanya memiliki hubungan yang kuat antar masing-masing pelaku usaha digital, yang menunjukkan angka minimal 0,1 telah menunjukkan hubungan yang kuat, sedangkan hubungan terkuat adalah koefisien 0,2 yaitu Tokopedia dengan Kudo, Tokopedia dengan Bukalapak dan Tokopedia dengan Grab. Hubungan kekuasaan ini berasal dari kebijakan yang muncul yang terlihat pada model Bisnis dan UKM Pendukung. Sedangkan yang tidak memiliki hubungan yang kuat adalah Tokopedia dengan Gojek, Kudo dengan Grab, Kudo dengan Bukalapak dan Grab dengan Bukalapak dengan skor masing-masing 0,03 berbanding -0,03. 


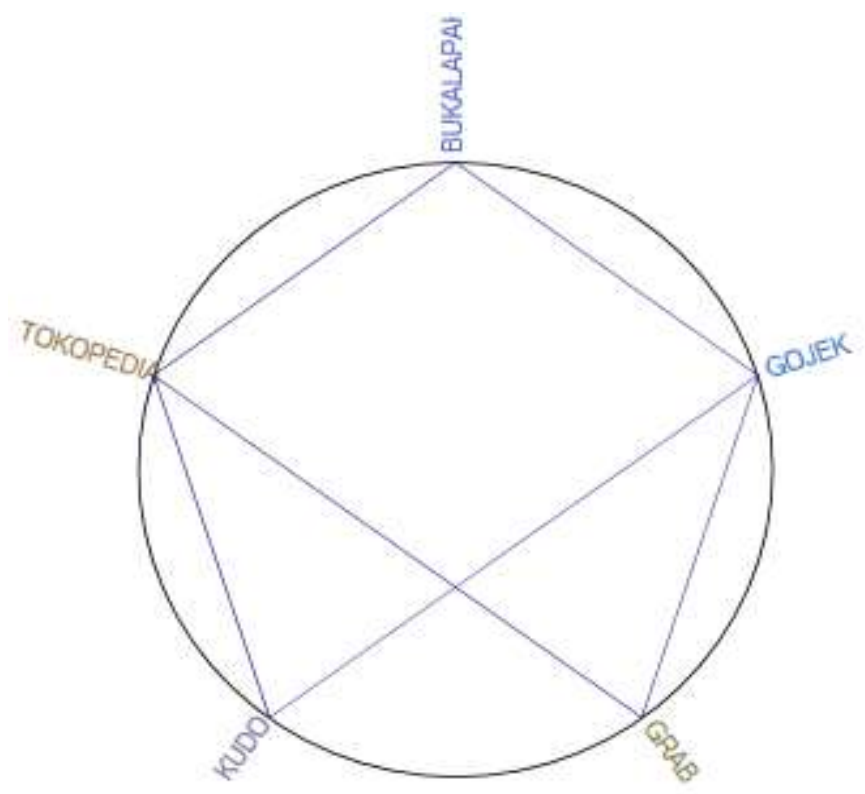

Sumber: output Nvivo

\section{Gambar 2. Cluster Analysis}

Hasil analisis diatas, baik dari Tabel 2 maupun Gambar 2, mempunyai tema yang memiliki korelasi kuat (Pearson Coefficient), Pada Gambar 2 terlihat sangat jelas bahwa garis biru menunjukkan korelasi yang kuat sedangkan yang kosong atau garis merah menunjukkan hubungan yang lemah.

Hubungan kuat terjalin antara Tokopedia dan Bukalapak, Grab, Kudo lalu Kudo dengan Tokopedia dan Gojek, kemudian hubungan Grab dengan Tokopedia dan Gojek, kemudian Gojek melawan Kudo dan Bukalapak, dan terakhir Bukalapak dengan Tokopedia dan Gojek.

Untuk relasi yang tidak kuat atau tidak muncul garis biru alias blank adalah Tokopedia dengan Gojek, Kudo dengan Grab, Kudo dengan Bukalapak dan Grab dengan Bukalapak.

\section{Project Map}

Salah satu fitur yang terdapat pada NVivo untuk menampilkan hasil penelitian adalah berupa peta. Istilah yang digunakan sebelumnya di NVivo adalah Model, tetapi sekarang telah diganti dengan istilah Map. Project Map: Map bersumber dari koding yang dibuat sebelumnya, apakah Files, Nodes, atau Relationships, hal ini mengacu pada tema hasil koding sehingga hasil koding dapat divisualisasikan

Peta proyek adalah cara untuk mengeksplorasi atau menyajikan data secara visual dalam suatu proyek. Peta proyek

terdiri dari bentuk-bentuk yang merepresentasikan berbagai objek dalam sebuah proyek dan tautan yang menunjukkan koneksi antar objek, dan tentunya membutuhkan beberapa data proyek sebelumnya untuk dapat membuat proyek. 
Dalam peta proyek, tahapan ini sangat membantu terutama dalam menganalisis, mengembangkan teori dan mempresentasikan hasil penelitian yang sedang dilakukan.

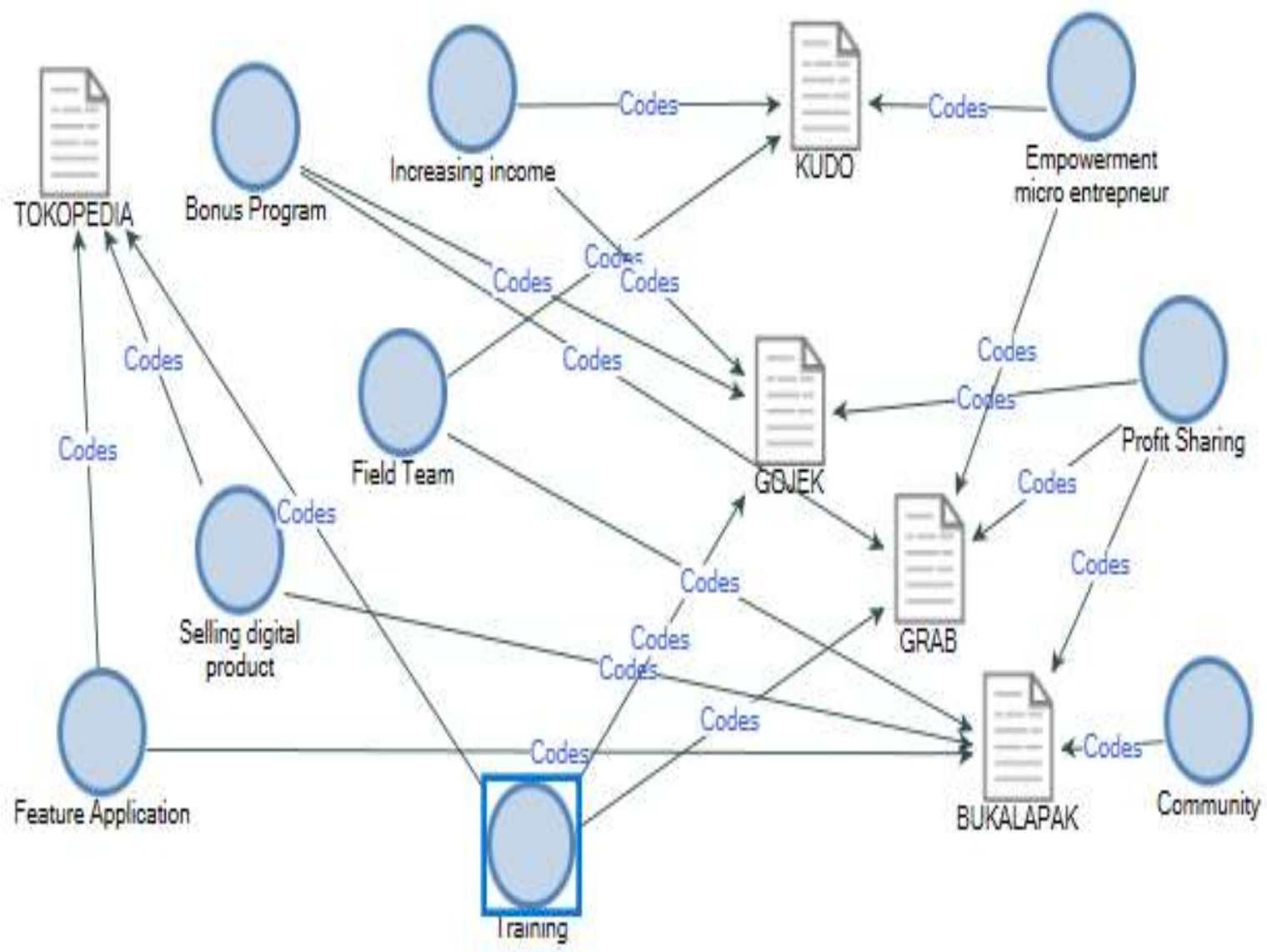

Source: output Nvivo

\section{Gambar 3. Project map}

9 program yang dikeluarkan oleh Business Digital Player, termasuk antara lain Bonus Program (BP), Income Increase (II), Field Team (FT), Empowerment of Micro Entrepreneurs (EME), Profit Sharing (PS), Selling Digital Product (SDP), Application Features (FA), Training (T) and community (C). Tokopedia memiliki SDP, FA, dan T. Kudo has II, FT, dan EME. Gojek memiliki II, BP, PS, dan T. Grab memiliki EME, BP, PS dan T, sementara Bukalapak memiliki C, PS, FA, SDP, dan FT.

Bukalapak paling agresif dengan memiliki 5 program untuk mendukung kemajuan Usaha Mikro, Kecil dan Menengah(UMKM), disusul oleh Gojek dan Grab yang memiliki 4 program unggulan dan yang terakhir adalah Kudo yang hanya memiliki 3 program pendukung untuk Usaha Mikro, Kecil dan Menengah(UMKM).

Program yang memiliki kesamaan dalam membentuk kebijakan untuk mendukung Usaha Mikro, Kecil dan Menengah(UMKM) adalah Pelatihan dan Bagi Hasil. Pelatihan didukung oleh Grab, Gojek, dan Tokopedian sedangkan Bagi Hasil didukung oleh Gojek, Grab, dan Bukalapak, yang lainnya memiliki kemiripan di beberapa fitur program namun rata-rata hanya memiliki 2 program unggulan yang sama. Ada yang unik dari program ini 
dimana semua Pelaku Bisnis Digital tidak menggunakan program ini yaitu Komunitas yang digunakan hanya oleh Bukalapak.

Jelas terlihat bahwa kesamaan kebijakan dalam menentukan program merupakan model kebijakan baru atau strategi baru dalam mendukung penggunaan e-commerce untuk kesejahteraan Usaha Mikro, Kecil dan Menengah(UMKM) yaitu Pelatihan dan Bagi hasil.

\section{Comparison Diagram}

Bagan perbandingan pada dasarnya untuk membantu dalam membandingkan tema secara khusus untuk menjelaskan perbandingan secara rinci. Diagram ini juga membandingkan partisipan satu sama lain atau data setting penelitian.

Diagram perbandingan dapat menunjukkan dua item apa yang memiliki kesamaan dan di mana perbedaannya. Ini dapat menghasilkan diagram perbandingan untuk membandingkan dua dari jenis item proyek yang sama-misalnya, file, node atau kasus untuk melihat persamaan dan perbedaannya.

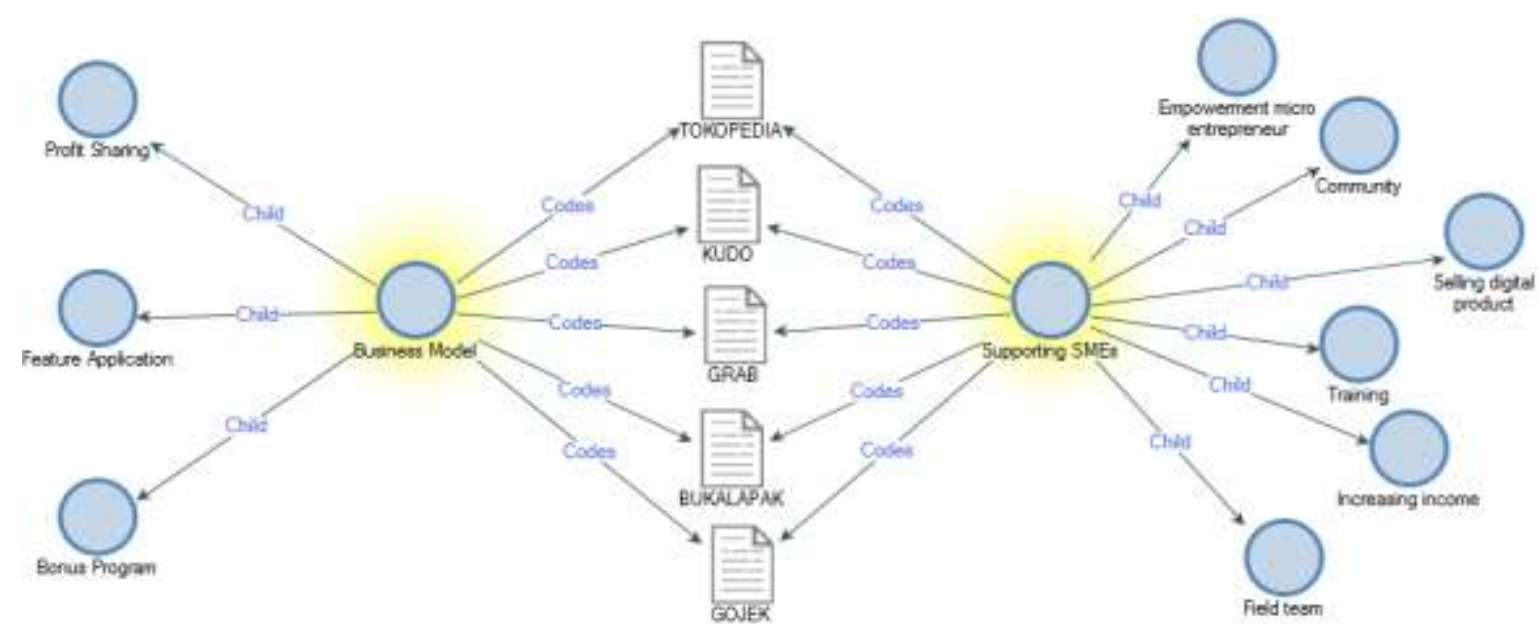

Source: output Nvivo

\section{Gambar 4. Comparison Diagram}

Dari gambar di atas, pelaku bisnis digital khususnya support SMEs lebih difokuskan pada: Empowering Micro Entrepreneurs(EME), Community $(\mathrm{C})$, Selling Digital Products(SDP), Training(T), Increasing Income(II) dan membantuk Field Teams(FT). Sementara itu, business model berfokus pada Profit Sharing(PS), Features Application(FA) dan Bonus Program(BP).

Pelaku bisnis digital yang terdiri dari Tokopedia, Kudo, Grab, Bukalapak dan Gojek. Ada 2 hal yang penting dalam mendukung kemajuan Usaha Mikro, Kecil dan Menengah(UMKM) dalam memajukan usahanya melalui penggunaan e-commerce yang tepat yaitu Business Model dan Supporting SMEs.

Model bisnis disini dimaksudkan sebagai motivasi bagi usaha mikro atau kecil dan menengah untuk mencapai tujuan keberhasilan usaha. Business model terdiri dari Profit Sharing(PS), Feature Application(FA) dan Bonus Program(BP), sememtara Supporting SMEs merupakan kegiatan yang secara langsung mendukung kemajuan yang dapat dirasakan dan dilihat oleh pengusaha Mikro, Kecil dan menengah(UMKM). Supporting SMEs terdiri dari Empowerment of Micro Entrepreneurs(EME), Selling Digital Products (SDP), Training(T), Increasing Income(II) dan Field Team(FT). 
Jika dilihat dari diagram perbandingan yang membentuk sebuah model bisnis bahwa para pelaku bisnis digital didukung oleh 2 hal penting yaitu Business Model dan Supporting SMEs untuk mendukung kemajuan Usaha Mikro, kecil dan menengah(UMKM), yang unik adalah lebih dominan kepada Supporting SMEs. UMKM lebih dari sekedar model bisnis, artinya pembentukan program dari Business Model tentunya harus dilakukan semaksimal mungkin dalam mendukung UMKM mulai dari hulu yaitu pembinaan dan pemberdayaan pengusaha mikro agar pengusaha lebih banyak. Ulet(Training), sedangkan hilir bagaimana menambah kenyamanan atau menambah penghasilan(Increasing Income), namun itu semua sudah dibuktikan dengan evaluasi dari Tim Lapangan (Field Team), tim lapangan yang selalu hadir untuk mengontrol kegiatan usaha yang telah dijalankan, salah satu yang paling terkenal dan lemah Poinnya adalah bagaimana cara menjual produk digital $(S D P)$ yang tepat. Semua hal di atas tidak mudah untuk dilakukan, tentunya harus ada pendekatan yang baik kepada masyarakat atau komunitasnya(Community), bagaimanapun canggihnya jika tidak tepat dalam mendekati masyarakat atau komunitas(Community), tetap akan menjadi batu sandungan dalam mencapai tujuan yang diharapkan.

\section{E. KESIMPULAN}

Adapun perbandingan 5 pelaku bisnis digital yang dipecah menjadi 2 (dua), yaitu Supporting SMEs terdiri dari Empowering Micro Entrepreneurs(EME), memiliki Community(C), Selling Digital Products(SDP), Increasing Income(II) dan Field Teams(FT), serta Business Model, terdiri dari Profit Sharing(PS), Features Application(FA) dan Bonus Program(BP).

Untuk model yang akan menghasilkan model terbaru dibentuk dari 5 pelaku bisnis digital, baik untuk Supporting SMEs maupun Business Model yaitu saling mendukung, dimana Bukalapak dan Gojek memiliki dominasi paling banyak yaitu sebanyak 4 tema. Bukalapak yaitu Selling Digital Products(SDP), Feature Applications(FA), Profit Sharing(PS) dan Field Teams(FT), dari 4 tema, 3 tema adalah Supporting SMEs dan hanya 1 untuk Business Model. Sementara Gojek antra lain Profit Sharing(PS), Bonus Program(BP), Training(T) dan Increasing Income(II). Dari 4 tema yang muncul, 2 berasal Supporting SMEs dan 2 berasal dari Business Models. Sedangkan yang paling sedikit adalah Tokopedia dan Kudo yang masing-masing hanya memiliki 2 tema yaitu Training(T), Features Application(FA), Increasing Income(II) dan Field Teams(FT), hanya ada satu untuk Business model yaitu Feature Application(FA).

Hasil analisis cluster menunjukkan bahwa hubungan Tokopedia dengan Gojek, Grab dan Bukalapak tidak kuat, namun di sisi lain model atau Project Map dan diagram perbandingan atau Comparison Diagram memiliki hubungan yang kuat sejalan dengan program yang telah dilaksanakan. Artinya hubungan dengan banyak kata yang mirip dalam pengambilan keputusan tidak serta merta memiliki hal yang sama bagi Pemain digital Busines(Business Digital Players) yang bersifat teknis atau strategis, akan tetapi perbedaan tersebut semuanya memberikan untuk memperkaya kemajuan Usaha Mikro, Kecil dan Menengah(UMKM) dalam menggunakan e-commerce sebagai kemajuan dalam bisnis. 
Begitu pula diagram perbandingan yang dipecah menjadi dua hal utama yaitu Business Model dan Supporting SMEs, bukan berarti tidak memiliki korelasi. Jika melihat Peta Proyek (Project Map) berikut detailnya, setiap program yang dijalankan dalam Business Model dan Supporting SMEs memiliki korelasi yang kuat, uniknya hanya ada satu kebijakan atau program yaitu Community tidak memiliki kesamaan dengan yang lain, yaitu dijalankan oleh pelaku atau pemain bisnis digital Bukalapak.

Hasil pemodelan di atas telah membentuk mayoritas tema untuk menunjang kesuksesan UKM di Indonesia, baik dari Supporting SMEs maupun Business Model.

Hasil penelitian ini diharapkan dapat bermanfaat bagi para pelaku bisnis digital(digital business players) yang fokus menggarap UMKM yang lebih maju di Indonesia, dan diharapkan penelitian ini dapat mengembangkan lebih banyak lagi terutama primer data dan sekunder data yaitu baik informan maupun data pendukung dalam membantu proses penelitian sehingga dapat menjadi kebijakan e-commerce bagi UMKM di Indonesia.

\section{REFERENCES}

Amoako, T., Huai Sheng, Z., Dogbe, C. S. K., \& Pomegbe, W. W. K. (2020). Effect of internal integration on SMEs' performance: the role of external integration and ICT. International Journal of Productivity and Performance Management. https://doi.org/10.1108/IJPPM-03-2020-0120

Bandur, A. (2019). Penelitian Kualitatif studi multi disiplin keilmuan dengan NVivo 12 plus. Jakarta: Mitra Wacana Media.

Doukidis, G. I., Lybereas, P. and Galliers, R. D. (1996). Information systems planning in small business: A stages of growth analysis. The Journal of Systems and Software, 33(2), 189.

Elsi anismar et al. (2019). Platform Pemberdaya UMKM. SWA, 22-47.

Hatammimi, J., \& Wulandari, D. A. (2014). Internal Factors that Motivate College Student to Become ICT-Based Entrepreneur. In Proceedings of International Conference on Research Methods in Management and Social Sciences (ICRMMS-2014) Internal (pp. 100-107).

Her, Y. L. (2020). Organisational capability on ict support and smes' performances in malaysia. Utopia y Praxis Latinoamericana, 25, 271-282. https://doi.org/10.5281/zenodo.4155593

Jackson \& Bazeley. (2013). Qualitative Data Analysis with NVivo. Losa Angeles, CA, USA: Sage Publication.

Jesson, J. K., Matheson, L., \& Lacey, F. M. (2011). Doing Your Literature Review traditional and systematic techniques. Sage Publication.

Keneth C . Laudon, J. P. . L. (2007). MANAGEMENT INFORMATION SYSTEMS :

Managing the Digital Firm - 9th edition, authors : Keneth C . Laudon and Jane P. Laudon (Book Review ). International Journal, 1(2), 103-105. https://doi.org/https://doi.org/10.15837/ijccc.2007.1.2342 
Lesmana, R., Sunardi, N., Hastono, H., \& Widodo, A. S. (2021). Perceived Quality Membentuk Customer Loyalty via Brand Equity pada Pengguna Smartphone Merek Xiaomi di Tangerang Selatan. Jurnal Pemasaran Kompetitif, 4(2), 157-167.

Lesmana, R., Habiyah, W., \& Nabila, N. I. (2020). Peran Kepuasan Wisatawan Terhadap Loyalitas Wisatawan Pada Objek Wisata Kepulauan Seribu Jakarta. JIMF (Jurnal IImiah Manajemen Forkamma), 3(2).

Miles, M. B., Huberman, A. M., \& Saldaña, J. (2014). Qualitative data analysis: a methods sourceboo (Third Edit). United States of America: Sage Publication.

Niode, I. Y. (2009). Sektor UMKM Di Indonesia: Profil , Masalah, dan Strategi Pemberdayaan. Jurnal Kajian Ekonomi Dan Bisnis OIKOS-NOMOS, 2.

Payne, J. E. (2001). E-Commerce Readiness for SMEs in Developing Countries: A Guide For Development Professionals. Retrieved from http://learnlink.aed.org/Publications/Concept_Papers/ecommerce_readiness.pdf\%0A

Purssell, E., \& McCrae, N. (2020). How to Perform a Systematic Literature Review. switzerland: Springer Nature Switzerland AG.

Qosasi, A., Permana, E., Muftiadi, A., Purnomo, M., \& Maulina, E. (2019). Building SMEs ' Competitive Advantage and the Organizational Agility of Apparel Retailers in Indonesia : The role of ICT as an Initial Trigger. Gadjah Mada International Journal of Business, 21(1), 69-90.

QS international. (2019). Nvivo 11 for windows help- about project map. Retrieved from www.qsinternasional.com

Rusgowanto, F. H. (2020). ICT implementation in android applications for entrepreneurship learning: A high school case study in Jakarta. International Journal of Innovation, Creativity and Change, 10(11), 68-82.

Schneider, G. P. (2002). Electronic commerce. Australia: Course Technology.

Siahaan, D. T., \& Tan, C. swee lin. (2020). Antecedents of Innovation Capability and Firm Performance of Indonesian ICT SMEs. Asian Journal of Business Research, 10(2), 45-71. https://doi.org/10.14707/ajbr.200083

Sunardi, N., \& Lesmana, R. (2020). Konsep Icepower (Wiramadu) sebagai Solusi Wirausaha menuju Desa Sejahtra Mandiri (DMS) pada Masa Pandemi Covid-19. JIMF (Jurnal IImiah Manajemen Forkamma), 4(1).

Sutarman, A., \& Lesmana, R. (2019). Analisis Keputusan Pembelian Konsumen dari Sisi Normtif dan Informatif Pada Supermarket Giant Pamulang, Tangerang Selatan. PROCEEDINGS UNIVERSITAS PAMULANG, 1(1).

Tambunan. (2006). Development of Small and Medium Enterprises in Indonesia. Retrieved from http://www.kadin-indonesia.or.id/enm/images/dokumen/KADIN-98-156702032007.pdf

Woolf, N. H., \& Silver, C. (2018). QUALITATIVE ANALYSIS USING NVivo, The Five- Level $Q D A \circledast$ Method. New York: Routledge.

Yunis, M., El-Kassar, A.-N., \& Tarhini, A. (2017). Impact of ICT-based innovations on organizational performance. Journal of Enterprise Information Management, 30(1), 